\title{
CERTAIN INEQUALITIES FOR CONVEX FUNCTIONS
}

\author{
ZlatKo PAVIĆ
}

Abstract. This is a review paper on some new inequalities for convex functions of one and several variables. The most important result presented for convex functions of one variable is the extension of Jensen's inequality to affine combinations. The most interesting results presented for convex functions of several variables refer to inequalities concerning simplexes and its cones.

Mathematics subject classification (2010): 26A51, 26B25, 52A20, 52B11.

Keywords and phrases: affine combination, simplex, hyperplane, Jensen's inequality.

Acknowledgement. This research was supported by Croatian Science Foundation under the project 5435 .

\section{REFERENCES}

[1] M. BJeliCA, Refinement and converse of Brunk-Olkin inequality, J. Math. Anal. Appl. 272 (1998), 462-467.

[2] J. L. W. V. Jensen, Om konvekse Funktioner og Uligheder mellem Middelvardier, Nyt tidsskrift for matematik. B. 16(1905), 49-68.

[3] B. JESSEN, Bemarkninger om konvekse Funktioner og Uligheder imellem Middelvardier. I., Matematisk tidsskrift. B. 2 (1931), 17-28.

[4] A. MCD. Mercer, A variant of Jensen's inequality, JIPAM, 4 (2003), Article 73.

[5] C. P. Niculescu And L. E. Persson, Old and new on the Hermite-Hadamard inequality, Real Anal. Exchange 29 (2003), 663-685.

[6] M. NiEzGodA, A generalization of Mercer's result on convex functions, Nonlinear Anal. 71 (2009) 2771-2779.

[7] Z. Pavić, Functions like convex functions, J. Funct. Spaces 2014 (2014), Article ID 919470, in Press.

[8] Z. PAVIĆ, Extension of Jensen's inequality to affine combinations, J Inequal Appl 2014 (2014), Article 298.

[9] Z. PAVIĆ, Generalizations of Jensen-Mercer's Inequality, JPAM:AA 11 (2014), 19-36.

[10] Z. PAVIĆ AND S. Wu, Inequalities for convex functions on simplexes and their cones, Abstr. Appl. Anal. 2014 (2014), Article ID 690803.

[11] J. E. PEČARIĆ, A simple proof of the Jensen-Steffensen inequality, Amer. Math. Monthly 91 (1984) 195-196.

[12] J. PEČARIĆ, A. PERUŠIĆ AND K. SMOLJAK, Mercer and Wu-Srivastava generalisations of Steffensen's inequality, Appl. Math. Comput. 219 (2013), 10548-10558.

[13] J. E. Pečarić, F. Proschan And Y. L. Tong, Convex Functions, Partial Orderings, and Statistical Applications, Academic Press, New York, USA, 1992.

[14] I. RAŞA, A note on Jensen's inequality, in Itinerant Seminar on Functional Equations, Approximation and Convexity, Universitatea Babes-Bolyai, Cluj-Napoca, (1988), 275-280.

[15] E. J. McShane, Jensen's inequality, Bull. Amer. Math. Soc. 43 (1937), 521-527.

[16] R. T. Rockafellar, Convex Analysis, Princeton University Press, New Jersey, USA, 1972. 